\title{
JNPH
}

Volume 6 No. 2 (Oktober 2018)

(C) The Author(s) 2018

\section{GAMBARAN KADAR KREATININ DARAH PADA PASIEN \\ PENYAKIT JANTUNG KORONER DI RUANG ICCU \\ RSUD DR. M.YUNUS PROVINSI BENGKULU}

\section{DESCRIPTION OF BLOOD CREATININ LEVELS IN PATIENTS CORONARY HEART DISEASE IN THE ICCU SPACE RSUD DR. M. YUNUS OF BENGKULU PROVINCE}

\author{
DICKY ARDIANSYAH ${ }^{1}$, JON FARIZAL ${ }^{2}$, DIRA IRNAMERIA ${ }^{3}$ \\ PRODI D-III ANALIS KESEHATAN POLTEKKES KEMENKES BEGKULU \\ JALAN INDRAGIRI NOMOR 03 PADDANG HARAPAN KOTA BENGKULU 38225 \\ E-mail : dickyardiansyahlagi@yahoo.co.id
}

\begin{abstract}
ABSTRAK
Latar Belakang: Penyakit jantung koroner (PJK) adalah penyakit jantung pembuluh darah yang disebabkan karena penyempitan arteri koroner. Penyempitan pembuluh darah terjadi karena aterosklerosis atau spasme atau keduanya, sehingga dapat mengakibatkan terjadi ketidakseimbangan antara suplai oksigen dan kebutuhan oksigen. Menurut World Health Organizations (WHO) jumlah orang yang meninggal akibat jantung di dunia setiap tahun diperkirakan sekitar 15 juta orang, sama dengan 30\% total kematian di dunia. Kreatinin merupakan hasil pemecahan kreatin fosfat otot, diproduksi oleh tubuh secara konstan tergantung massa otot dan secara normal akan dikeluarkan dari dalam pembuluh darah melalui ginjal, sehingga peningkatan kadar kreatinin dapat menunjukan terjadinya kegagalan fungsi ginjal. Nilai kreatinin yang meningkat menunjukan penurunan fungsi ginjal. Penurunan fungsi ginjal akan meningkatkan faktor resiko penyakit kardiovaskular seperti penyakit jantung koroner.Tujuan : Untuk mengetahui gambaran kadar kreatinin pada pasien penyakit jantung koroner di ruang rawat inap ICCU RSUD dr. M.Yunus Provinsi Bengkulu.Metode: Penelitian ini menggunakan jenis penelitian survey deskriptif dengansampel sebanyak 31 orang dengan menggunakan metode Accidental sampling. Sampel diukur dengan alat Architect C4000.Hasil : Hasil penelitian menunjukan bahwa sebagian besar responden kadar kreatinin darah normal adalah $74,19 \%$ dan sebagian kecil responden kadar kreatinin meningkat adalah $25,81 \%$ Kesimpulan : gambaran kadar kreatinin darah pada penderita penyakit jantung koroner di ruang ICCU RSUD dr. M.Yunus Provinsi Bengkulu menunjukkan bahwa 74,19\% pasien memiliki kadar kreatinin normal dan 25,81\% pasien memiliki kadar kreatinin meningkat.
\end{abstract}

Kata Kunci : Penyakit Jantung Koroner, Kreatinin.

\begin{abstract}
Background: Coronary heart disease (CHD) is a blood vessel heart disease caused by narrowing of the coronary arteries. Narrowing of blood vessels occurs due to atherosclerosis or spasm or both, so it can result in an imbalance between oxygen supply and oxygen demand. According to the World Health Organizations (WHO) the number of people who die from the heart in the
\end{abstract}


world each year is estimated at around 15 million people, equal to $30 \%$ of the total deaths in the world. Creatinine is the result of muscle breakdown of creatine phosphate, produced by the body constantly depending on muscle mass and normally released from the blood vessels through the kidneys, so that an increase in creatinine levels can indicate kidney failure. Increased creatinine values show decreased kidney function. Decreased kidney function will increase risk factors for cardiovascular diseases such as coronary heart disease. Objective: To describe the creatinine levels in patients with coronary heart disease in the ICCU inpatient unit of RSUD dr. M. Yunus Bengkulu Province. Method: This study used a descriptive survey research with a sample of 31 people using the Accidental sampling method. The sample was measured by Architect C4000 tool. Results: The results showed that the majority of respondents normal blood creatinine levels were $74.19 \%$ and a small percentage of respondents increased creatinine levels were $25.81 \%$. Conclusion: description of blood creatinine levels in coronary heart disease patients in the room ICCU RSUD dr. M. Yunus Bengkulu Province showed that $74.19 \%$ of patients had normal creatinine levels and $25.81 \%$ of patients had increased creatinine levels.

\section{Keywords: Coronary Heart Disease, Creatinine.}

\section{PENDAHULUAN}

Pada saat ini penyakit jantung merupakan penyebab kematian nomor satu di dunia. Pada tahun 2005 sedikitnya 17,5 juta atau setara dengan 30\% kematian di seluruh dunia disebabkan oleh penyakit jantung. Menurut Badan Kesehatan Dunia (WHO), $60 \%$ dari seluruh penyebab kematian penyakit jantung adalah penyakit jantung koroner (PJK)[1].Menurut World Health Organizations (WHO) jumlah orang yang meninggal akibat jantung di dunia setiap tahun diperkirakan sekitar 15 juta orang, sama dengan 30\% total kematian di dunia[1]. Saat ini Indonesia telah terjadi pergeseran kejadian penyakit jantung dan pembuluh darah dari urutan ke-10 tahun 1980 menjadi urutan ke-8 tahun 1986. Sedangkan penyebab kematian tetap menduduki peringkat ketiga. Banyak faktor yang mempengaruhi terjadinya PJK yang sebenarnya dapat dicegah, akan tetapi angka kematian di Indonesia cenderung terus meningkat. Pencegahan harus multifaktorial dengan cara pengendalian faktor risiko PJK, baik primer maupun sekunder. Pencegahan primer lebih ditujukan pada mereka yang sehat tetapi mempunyai risiko tinggi, sedangkan pencegahan sekunder merupakan upaya memburuknya penyakit yang secara klinis telah diderita. Keberhasilan upaya pencegahan di negara maju terlihat dengan berkurangnya angka kejadian PJK, di mana sistem penanggulangan PJK sudah terstruktur rapi[2].

Penderita penyakit jantung koroner, gagal jantung dan stroke banyak ditemukan pada kelompok umur 45-54 tahun, 55-64 tahun dan 65-74 tahun. Namun demikian, berdasarkandiagnosis/gejala, penyakit jantung koroner, gagal jantung dan stroke cukup banyak pula ditemukan pada penduduk kelompok umur 15-24 tahun[3].Data yang tercatat di Dinas Kesehatan Kota Bengkulu pada tahun 2013 tercatat angka kejadian penyakit jantung koroner di Kota Bengkulu mencapai angka 227 kasus, tahun 2014 tercatat 200 kasus, tahun 2015 tercatat 218 kasus, dan ditahun 2016 tercatat 443 kasus. Ada peningkatan prevalensi dari penyakit jantung koroner di kota Bengkulu, ini menandakan bahwa selama 4 tahun terakhir penyakit jantung koroner cenderung meningkat di kota Bengkulu [4].

$$
\text { Penyakit Jantung Koroner (PJK) }
$$
merupakan kondisi yang terjadi akibat penumpukan plak di arteri jantung sehingga terjadi penyempitan arteri yang mengakibatkan kurangnya suplai oksigen ke seluruh tubuh[5].Pada keadaan patologis penyakit jantung koroner seperti adanya lesi aterosklerosis, merangsang pelepasan 
endothelial derived contracting factor (EDCF) yang menyebabkan terjadinya konstriksi pembuluh darah termasuk pembuluh-pembuluh darah ginjal. Konstriksi pembuluh darah ginjal akan menyebabkan terjadinya penurunan aliran darah ke ginjal sehingga terjadi penurunan laju filtrasi glomerulus[6].Untuk melihat kontriksi pada ginjal penderita jantung koroner, kreatinin darah dapatberperan sebagai penanda penyakit vaskular umum. Pentingnya prognostik kreatinin serum dalam kejadian penyakit jantung koroner dapat menjadi acuan dalam pemeriksaan fungsi ginjal[7].

Berdasarkan uraian tersebutmaka peneliti tertarik melakukan penelitian tentang"Gambaran kadar kreatinin darah pada penderita penyakit jantung koroner di ruang ICCU RSUD dr. M.Yunus Provinsi Bengkulu" karena adanya peningkatan kreatinin serum dapat menjadi faktor untuk semua penyebab dan kematian penyakit kardiovaskular.

\section{METODE PENELITIAN}

Penelitian ini menggunakan jenis penelitian survei deskriptif yang dilakukan untuk mendeskripsikan atau menggambarkan suatu fenomena yang terjadi di masyarakat[8], penelitianini dilakukan dengan pendekatan laboratorium yaitu dilakukan langsung pengukuran kadar kreatinin pada penderita penyakit jantung koroner.

Populasi penelitian ini adalah adalah pasien penyakit jantung koroner yang melakukan rawat inap ICCU pada bulan Januari-September 2017 yaitu 110 orang di RSUD dr. M.Yunus Provinsi Bengkulu.

Sampel yang digunakan dalam penelitian ini adalah pasien penyakit jantung koroner yang melakukan rawat inap ICCU RSUD dr. M.Yunus Provinsi Bengkulu , dengan memakai teknik Accidental Sampling. Pengambilan besar sampel ditentukan dengan rumus:

$=\left(\mathrm{Nx} Z^{\wedge} 21-\alpha / 2 x \mathrm{P}(1-\mathrm{P})\right) /\left((\mathrm{N}-1) \mathrm{d}^{\wedge} 2+\mathrm{Z}^{\wedge} 21-\right.$ $\alpha / 2 \times P(1-P))$

Berdasarkan perhitungan dengan rumus besar sampel diatas diperoleh jumlah sampel penelitian yaitu 31 orang. Sampel penelitian diambil dengan menggunakan metode Accidental sampling yaitu mengambil responden yang kebetulan ada atau bersedia yang sesuai dengan konteks penelitian [8].

Penelitian ini dilakukan di Laboratorium RSUD dr. M.Yunus Provinsi Bengkulu.

\section{HASIL PENELITIAN}

Analisa univariat digunakan untuk melihat distribusi frekuensi gambaran kadar kreatinin darah pada penderita penyakit jantung koroner di ruang ICCU RSUD dr. M.Yunus Provinsi Bengkulu. Hasilnya dapat dilihat pada tabel berikut :

Tabel 1. Distribusi Frekuensi kadar kreatinin darahpada penderita penyakit jantung koroner di ruang ICCU RSUD dr. M.Yunus Provinsi Bengkulu

\begin{tabular}{ccc}
\hline $\begin{array}{c}\text { Kadar } \\
\text { Kreatinin } \\
\text { darah }\end{array}$ & Frekuensi & Persentase \\
\hline Normal & 23 & $74,19 \%$ \\
\hline Meningkat & 8 & $25,81 \%$ \\
\hline Total & 31 & $100 \%$ \\
\hline
\end{tabular}

Tabel 1 dapat diketahu bahwa sebagian besar responden yang memiliki kadar kreatinin darah normal sebanyak 74,19\% dan sebagian kecil responden yang memilikikadar kreatinin meningkat sebanyak $25,81 \%$.

\section{PEMBAHASAN}

Pada penelitian ini diperoleh hasil kadar kreatinin meningkat sebanyak 8 orang responden $(25,81 \%)$, terdiri dari 6 orang lakilaki dan 2 orang perempuan. Hal ini disebabkan karena penumpukan lemak yang berlebihan di pembuluh darah arteri sehingga 
terjadi penyempitan arteri yang mengakibatkan kurangnya suplai oksigen ke seluruh tubuh termasuk ke ginjal, sehingga memicu kadar kreatinin meningkat. Data hasil pengukuran kadar kreatinin juga menunjukkan bahwa pasien yang berusia $>50$ tahun cenderung memiliki kadar kreatinin tinggi. Penelitian Kristin pada tahun 2016 juga menunjukkan hasil yang sama.

Pada penelitian ini didapatkan persentase jumlah pasien yang memiliki kadar kreatinin normal $74,19 \%$ ( 23 orang ) yang terdiri dari 8 orang wanita dan 15 orang lakilaki. Hal ini menunjukkan bahwa pasien tersebut telah melakukan prosedur pengobatan yang baik yaitu mengontrol kadar kolesterol dan tekanan darah. Tekanan darah yang tinggi bisa menjadi penanda lesi aterosklerosis yang merusak jantung. Dari 8 orang pasien wanita yang memiliki kadar kreatinin normal, terdapat 1 orang yang belum memasuki usia menopause (berusia $<50$ tahun). Hal ini menunjukkan bahwa wanita yang belum memasuki usia menopause memiliki hormon estrogen yang berfungsi sebagai protektan terhadap kejadian aterosklerosis[6].

Penelitian serupa juga pernah dilakukan oleh Kristin tahun 2016menunjukkan bahwa dari 73 kasus penyakit jantung, 34 orang diantaranya mengalami penurunan Laju Filtrasi Glomerulus (LFG) dan 39 orang normal. Dari 34 orang yang mengalami penurunan, 30 orang diantaranya mengalami penurunan Laju Filtrasi Glomerulus (LFG) yang disertai dengan penyakit penyerta seperti hipertensi dan kadar trigliserida yang tinggi.

Penelitian Akanda tahun2016 menunjukkan bahwa secara statistik ada perbedan yang siginifikan terhadap hasil kadar kreatinin serum pada pasien non PJK $((92,89 \pm 20,82 \mu \mathrm{mol} / \mathrm{L})$ dan pasien PJK $(108,68 \pm 23,62 \mu \mathrm{mol} / \mathrm{L})$ dengan probabilitas $<0,05$.

untuk $\begin{array}{r}\text { Pemeriksaan } \\ \text { mengukur }\end{array}$ glomerulus, dan juga untuk memantau perjalanan penyakit ginjal.Diagnosis gagal ginjal dapat ditegakkan saat nilai kreatinin serum meningkat di atas nilai rujukan normal. Pada keadaan gagal ginjal dan uremia, ekskresi kreatinin oleh glomerulus dan tubulus ginjal menurun [9].

Kadar kreatinin serum sudah banyak digunakan untuk penunjang penyakit jantung koroner. Rehbeg menyatakan peningkatan kadar kreatinin serum antara 1,2-2,5 mg/ dL berkorelasi positif terhadap tingkat keparahan penyakit Jantung Koroner. Beberapa penelitian mengevaluasi adanya hubungan positif antara penyakit kardiovaskuler dengan peningkatan kadar kreatinin serum [10] .

Walaupun tidak berhubungan secara langsung, kreatinin dapat dihubungkan dengan fungsi ginjal dan masih digunakan untuk menghitung laju filtrasi glomerulus. Nilai kreatinin yang meningkat menunjukkan penurunan fungsi ginjal. Penurunan fungsi ginjal akan meningkatkan faktor risiko penyakit kardiovaskular seperti peningkatan kadar homosistein, stres oksidatif, partikel kolesterol, serta remodeling ventrikel[10].

\section{KESIMPULAN}

Berdasarkan hasil dan pembahasan, maka dapat disimpulkan bahwa gambaran kadar kreatinin darah pada penderita penyakit jantung koroner di ruang ICCU RSUD dr. M.Yunus Provinsi Bengkulu Tahun 2018 menunjukkan bahwa $74,19 \%$ pasien memiliki kadar kreatinin normal dan $25,81 \%$ pasien memiliki kadar kreatinin meningkat.

\section{SARAN}

Kepada peneliti selanjutnya
diharapkan agar berupaya lebih
mengembangkan dan memperdalam bahasan
tentang gambaran kadar kreatinin darah pada
pasien penyakit jantung koroner dengan
menggunakan desain penelitian yang berbeda.

\section{DAFTAR PUSTAKA}

Akanda, M. A. K., Choudhury, K. N., Ali, M. Z., Kabir, M. K., Begum, L. N., \& 
Sayami, L. A. (2016). Serum Creatinine and Blood Urea Nitrogen Levels in Patients with Coronary Artery Disease, 3-8.

Amandini, A. (2016). Nilai Kreatinin Sebagai Faktor Prediktor Keparahan Penyakit Jantung Koroner Berdasarkan Sullivan Vessel sScore. Jakarta.

Data Dinas Kesehatan Kota Bengkulu (2016).

Kristin, A. M., Panda, A. L., \& Janry Panemanan. (2016). Gambaran Fungsi Ginjal Pada Penderita Sindrom Koroner Akut, 4, 2-7.

Notoadmodjo, S. (2010). Metodologi Penelitian Kesehatan. Jakarta: PT Rineka Cipta

Oemiyati, R., \& Rustika, R. (2015). Faktor risiko penyakit jantung koroner (pjk) pada perempuan (Baseline Studi Kohor Faktor Risiko PTM) (Risk Factors for Coronary Heart Disease (CHD) in Women [Baseline Cohort Study of Risk Factors for Non Communicable Disease]). Buletin Penelitian Sistem Kesehatan, 18(1), 47-55

Palar, S. (2014). Hubungan beberapa faktor risiko penyakit jantung koroner dengan laju filtrasi glomerulus pada pasien infark miokard lama

Pusat Data dan Informasi Kementerian Kesehatan RI. (2017). InfoDATIN. Infodatin Pusat Data Dan Informasi Kementerian Kesehatan RI.

Ricobain. (2011). deteksi dini dan pencegahan kolesterol dan penyakit jantung. Jogjakarta

Verdiansah. (2016). Pemeriksaan Fungsi Ginjal. Cermin Dunia Kesehatan, 43(2), 148-154. 